\title{
PELAKSANAAN PENERBITAN BANK GARANSI SETELAH TERBITNYA PERPRES NO 95 TAHUN 2007 PADA BNI CABANG DENPASAR*
}

\author{
Oleh : \\ Ni Putu Purnama Andari ${ }^{* *}$ \\ Ida Bagus Putra Atmadja ${ }^{* * *}$ \\ Ida Bagus Putu Sutama**** \\ Program Kekhususan Hukum Bisnis, Fakultas Hukum, \\ Universitas Udayana
}

\begin{abstract}
ABSTRAK
Bank Garansi merupakan jaminan dalam bentuk surat jaminan yang diberikan oleh bank kepada nasabah untuk melindungi kepentingan pihak ketiga. Penerbitan Bank Garansi sudah seharusnya berpedoman pada peraturan yang berlaku. Permasalahan yang dapat diangkat adalah bagaimana pelaksanaan penerbitan bank garansi setelah terbitnya Perpres Nomor 95 Tahun 2007 Tentang Perubahan Ketujuh atas Keputusan Presiden Nomor 80 Tahun 2003 tentang Pedoman Pelaksanaan Pengadaan Barang/Jasa Pemerintah. Bagaimana upaya BNI untuk menyelesaikan permasalahan terkait waktu penerbitan bank garansi setelah dikeluarkannya Perpres Nomor 95 Tahun 2007. Tujuan penulisan jurnal ini adalah untuk mengetahui pelaksanaan penerbitan bank garansi pada BNI Cabang Denpasar dan Upaya bank untuk menyelesaikan permasalahan terkait waktu penerbitan bank garansi setelah terbitnya Perpres Nomor 95 Tahun 2007. Metode yang digunakan dalam penelitian ini adalah metode hukum empiris. Hasil studi menunjukkan setelah diterbitkannya Perpres

* Tulisan ini merupakan ringkasan dari Skripsi yang berjudul "Implementasi Surat Edaran Bank Indonesia Nomor 23/7/UKU Terkait Dengan Wanprestasi Dalam Pemberian Bank Garansi Kepada Nasabah Pada PT. Bank Negara Indonesia (Persero) Tbk Cabang Denpasar”.

** Penulis Pertama : Ni Putu Purnama Andari adalah mahasiswa Fakultas Hukum Universitas Udayana, Korespondensi : andaripurnama96@gmail.com.

*** Penulis Kedua : Ida Bagus Putra Atmadja adalah Dosen Fakultas Hukum Universitas Udayana.

${ }^{* * * *}$ Penulis Ketiga : Ida Bagus Putu Sutama adalah Dosen Fakultas Hukum Universitas Udayana.
\end{abstract}


Nomor 95 Tahun 2007 pelaksanaan penerbitan bank garansi dijalankan seperti sebelum diterbitkannya Perpres Nomor 95 Tahun 2007, namun ada satu kendala yang muncul setelah terbitnya Kepres ini yaitu waktu penerbitan bank garansi, karena adanya norma yang bertentangan antara Perpres Nomor 95 Tahun 2007 dengan SEBI Nomor 23/7/UKU Tahun 1971. Upaya Bank untuk menyelesaikan permasalahan terkait dengan waktu penerbitan bank garansi karena adanya ketidaksesuain peraturan yakni dengan mengambil kebijakan sendiri dengan mensyaratkan Surat Perintah Kerja (SPK) dalam pengajuan permohonan bank garansi sebagai dasar transaksi surat berharga.

\title{
Kata Kunci : Pelaksanaan, Bank Garansi, Nasabah
}

\begin{abstract}
Bank Guarantee is a guarantee in the form of a guarantee letter given by the bank to a customer to protect the interests of a third party. Issuance of Bank Guarantees should be guided by applicable regulations. The problem that can be raised is how the implementation of bank guarantee issuance after the issuance of Presidential Regulation Number 95 of 2007 concerning the Seventh Amendment to Presidential Decree Number 80 of 2003 concerning Guidelines for the Implementation of Government Goods / Services Procurement. What is BNI's efforts to solve the problems related to the issuance of bank guarantees after the issuance of Presidential Regulation No. 95 of 2007. The purpose of writing this journal is to find out the implementation of bank guarantees at BNI Denpasar Branch and bank efforts to resolve problems related to bank guarantee issuance after the issuance of Presidential Regulation No. 95 2007. The method used in this study is the empirical legal method. The study shows that after the issuance of Presidential Regulation No. 95 of 2007 the implementation of bank guarantee issuance was carried out as before the issuance of Presidential Regulation No. 95 of 2007, but there was one obstacle that emerged after the issuance of this Presidential Decree was the issuance of bank guarantees due to conflicting norms between Presidential Regulation Number 95 Year 2007 with SEBI Number 23/7 / UKU in 1971. The Bank's efforts to resolve problems related to the issuance time of bank guarantees due to regulatory mismatches by taking its own policy by requiring a Work Order (SPK) in submitting bank guarantee applications as the basis for securities transactions.
\end{abstract}

Keywords: Implementation, Bank Guarantee, Customer 


\section{PENDAHULUAN}

\subsection{Latar Belakang}

Bank merupakan lembaga keuangan yang kegiatannya meliputi menghimpun dana masyarakat, menyalurkan dana berupa kredit, dan menyediakan jasa - jasa bank lainnya untuk membantu kehidupan masyarakat. Bank garansi merupakan salah satu jasa yang disediakan oleh bank. Yang dimaksud dengan bank garansi adalah jaminan pembayaran yang diberikan oleh bank kepada suatu pihak baik perorangan, perusahaan atau badan/lembaga lainnya dalam bentuk surat jaminan. ${ }^{1}$

Dasar bank garansi adalah penanggungan (borgtocht) yang diatur dalam Pasal 1820 KUH Perdata sampai dengan Pasal 1850 KUH Perdata. ${ }^{2}$ Penerbitan garansi memiliki beberapa tujuan sesuai dengan fungsi bank garansi, namun secara umum penerbitan bank garansi memiliki tujuan yakni : 1) Bagi bank tujuannya adalah memberikan bantuan dalam memperlancar transaksi nasabah dalam menjalankan usaha atau proyeknya, 2) Bagi Penerima Jaminan (Pemberi kerja) adalah memberikan keyakinan bahwa pemegang jaminan tidak akan mengalami kerugian bila pihak yang dijaminkan melalaikan kewajibannya. Bank garansi hanya berlaku untuk 1 kali transaksi sampai dengan tanggal berakhirnya, tidak boleh diperpanjang, namun nasabah boleh mengajukan permohonan untuk memperbaharui bank garansi tersebut. ${ }^{3}$

Penerbitan bank garansi sudah seharusnya sesuai dengan peraturan yang mengatur mengenai bank garansi, agar dapat

\footnotetext{
${ }^{1}$ Putu Novi Pujayanti, I Nyoman Bagiastra, 2014, Kedudukan Bank Dalam Pemberian Bank Garansi, Vol.02, No.05, Juli 2014, h.3. Kerta Semaya (URL : https://ojs.unud.ac.id/index.php/kerthasemaya/article/view/9551) Diakses pada tanggal 22 Januari 2019

2 P.N.H. Simanjuntak, 2016, Hukum Perdata Indonesia, Cetakan II, Prenadamedia Group, Jakarta, h.321

${ }^{3}$ Kasmir, 2016, Dasar-Dasar Perbankan, Rajawali Pers, Jakarta, h.26
} 
mengurangi kasus-kasus wanprestasi dalam pelaksanaan bank garansi. Sebelum dikeluarkannya Kepres Nomor 95 Tahun 2007 Perubahan Ketujuh Atas Keputusan Presiden Nomor 80 Tahun 2003 tentang Pedoman Pelaksanaan Pengadaan Barang/Jasa Pemerintah, pelaksanaan bank garansi pada BNI Cabang Denpasar berpedoman pada SEBI Nomor 23/7/UKU Tahun 1971 tentang Pemberian Garansi oleh Bank. Namun setelah dikeluarkan Perpres Nomor 95 Tahun 2007 BNI mengalami kendala mengenai waktu penerbitan bank garansi. Hal ini disebabkan karena adanya norma yang bertentangan pada Peraturan Presiden Nomor 95 Tahun 2007 tentang Perubahan Ketujuh Atas Keputusan Presiden Nomor 80 Tahun 2003 tentang Pedoman Pelaksanaan Pengadaan Barang/Jasa Pemerintah dengan SEBI Nomor 23/7/UKU tahun 1971 tentang Pemberian Garansi oleh Bank. Norma dalam kedua peraturan tersebut bertentangan, sehingga menimbulkan permasalahan dalam penerbitan bank garansi.

\subsection{Tujuan}

Tujuan dari penulisan ini adalah untuk mengetahui bagaimana pelaksanaan penerbitan bank garansi pada BNI Cabang Denpasar dan upaya bank untuk menyelesaikan permasalahan terkait waktu penerbitan bank garansi setelah terbitnya Perpres Nomor 95 Tahun 2007.

\section{ISI MAKALAH}

\subsection{Metode Penulisan}

Metode yang digunakan dalam penelitian ini adalah metode hukum empiris, dengan menggunakan data primer yang didapat dengan penelitian ke lapangan dan data sekunder yang di dapat dengan melakukan penelitian kepustakaan. Pada metode ini hal 
yang diiteliti bisa berkaitan dengan identifikasi hukum, efektivitas hukum serta pengaruh timbal balik dari suatu peraturan dan kenyataan pada masyarakat. ${ }^{4}$

\subsection{Hasil dan Pembahasan}

\subsubsection{Pelaksanaan Pemberian Bank Garansi Kepada Nasabah Pada Bank Negara Indonesia Cabang Denpasar}

Bank Negara Indonesia Cabang Denpasar merupakan salah satu bank yang menyediakan jasa Bank Garansi. Bank Garansi banyak digunakan oleh kontraktor yang akan menjalankan suatu proyek besar, karena dapat membantu para kontraktor agar dapat lancar dalam menjalankan proyeknya. Bank garansi merupakan perjanjian yang bersifat tambahan, adanya bank garansi ini karena adanya perjanjian pokok. ${ }^{5}$ Dalam pemberian bank garansi terdapat 3 pihak yang terlibat yaitu :

1. Penjamin (Bank)

2. Terjamin (Nasabah)

3. Pemberi Kerja 6

Dalam kegiatan pemberian jasa termasuk pemberian bank garansi sudah seharusnya setiap bank berpedoman pada peraturan yang mengatur tentang bank garansi. Sebelum dikeluarkannya Perpres 95 Tahun 2007 Tentang Perubahan Ketujuh atas Keputusan Presiden Nomor 80 Tahun 2003 tentang Pedoman Pelaksanaan Pengadaan Barang/Jasa Pemerintah, dalam penerbitan bank garansi pada BNI Cabang Denpasar berpedoman

\footnotetext{
${ }^{4}$ Bambang Sunggono, 2015, Metodologi Penelitian Hukum, Rajawali Pers, Jakarta, h. 42

${ }^{5}$ Salim HS, 2017, Perkembangan Hukum Jaminan di Indonesia, Cet.ke10, Rajawali Pers, Jakarta, h.234

${ }^{6}$ H.Malayu S.P Hasibuan, 2017, Dasar-Dasar Perbankan, Cet ke-11, Bumi Aksara, Jakarta,h.138
} 
pada KUHPer dan peraturan khusus yang mengatur tentang bank yakni SE BI Nomor 23/7/UKU tentang Pemberian Garansi Oleh Bank. ${ }^{7}$

Berdasarkan data yang diberikan oleh Ibu I Gusti A.N Sukesni sebagai Asisten Manager Frontliner, setelah dikeluarkannya Pepres 95 Tahun 2007 Tentang Perubahan Ketujuh atas Keputusan Presiden Nomor 80 Tahun 2003 tentang Pedoman Pelaksanaan Pengadaan Barang/Jasa Pemerintah, prosedur penerbitan bank garansi masih sama seperti sebelumnya. Ada beberapa tahapan penerbitan bank garansi yang dilakukan oleh BNI yakni :

1. Pemohon merupakan nasabah BNI

2. Nasabah mengajukan permohonan penerbitan bank garansi kepada BNI

Pada BNI Cabang Denpasar permohonan bank garansi dilaksanakan dengan beberapa tahap sesuai dengan yang sudah ditentukan, yakni meliputi :

a. Mengisi formulir Pengajuan Bank Garansi yang di dalamnya meliputi beberapa ketentuan terutama penegasan pasal yang dijadikan dasar pembayaran apabila terjadi klaim. (Pasal 1831 KUH Perdata atau Pasal 1832 KUH Perdata)

b. Memenuhi syarat-syarat Pendukung Pengajuan Bank Garansi

Nasabah juga harus memenuhi syarat-syarat pendukung, yakni meliputi ; 1) Foto copy KTP/SIM, Kartu Keluarga dan Akta Nikah, 2) Pasfoto, 3)Jaminan dan 4)

${ }^{7}$ H.R. Daeng Naja, 2005, Hukum Kredit dan Bank Garansi, Citra Aditya Bakti, Bandung, h.164 
Membayar Biaya Administrasi. Setelah semua syarat dipenuhi, maka permohonan penerbitan bank garansi akan diproses oleh bank.

3. Bank menganalisa permohonan bank garansi dari nasabah

Ada beberapa upaya yang dilakukan bank untuk mencegah adanya wanprestasi yakni dengan menganalisis nasabah yang mengajukan permohonan bank garansi sebelum permohonan disetujui. Bank menganalisis nasabah dengan menggunakan Formula 4P dan Prinsip 5C.

A. Formula 4P terdiri dari :

a. Personality : bank mengumpulka data lengkap mengenai kepribadian nasabah yang mengajukan permohonan bank garansi

b. Purpose : bank harus mengetahui tujuan dari penggunaan bank garansi

c. Prospect : bank melakukan analisis mengenai prospek kedepan dari proyek yang dikerjakan oleh nasabah.

d. Payment: bank harus mengetahui kemampuan nasabah untuk membayar utangnya sesuai dengan waktu yang diperjanjikan.

B. Prinsip 5C terdiri dari :

a. Character : bank menilai bagaimana karakter dari nasabah yang ingin mengajukan permohonan bank garansi.

b. Capacity : bank menganalisis bagaimana kemampuan nasabah untuk mengelola proyeknya, apakah proyeknya tersebut mempunyai prospek untuk kedepannya. 
c. Capital : bank meneliti berapa banyak modal yang digunakan untuk menjalankan proyek dari nasabah tersebut

d. Collateral : bank mengharusan nasabahnya untuk menyerahkan jaminan untuk melindungi bank dari kerugian.

e. Conditions of Economy : bank memperhatikan kondisi ekonomi dari nasabah untuk mencegah terjadinya kerugian terhadap bank.

4. Nasabah bank garansi menyediakan kontra bank garansi.

5. Bank memberikan surat persetujuan pinsip pemberian bank garansi

Setelah semua berkas lengkap kemudian berkas diperiksa oleh bank, apabila bank menganggap pemohon pantas menerima bank garansi, maka bank akan megeluarkan Surat Persetujuan Prinsip Pemberian Bank garansi

6. Nasabah dikenakan biaya administrasi

Dilihat dari prosedur pelaksanaan pemberian bank garansi di atas, BNI Cabang Denpasar selalu berpedoman kepada peraturan yang berkaitan dengan pemberian bank garansi. Namun bank dihadapkan dengan masalah yang cukup pelik mengenai waktu penerbitan bank garansi dan masalah wanprestasi. Berdasarkan Peraturan Presiden Nomor 95 Tahun 2007 tentang Perubahan Ketujuh Atas Keputusan Presiden Nomor 80 Tahun 2003 tentang Pedoman Pelaksanaan Pengadaan Barang/Jasa Pemerintah pada Pasal 31 ayat (1) menyebutkan bahwa kontrak ditandatangani setelah pihak menyerahkan jaminan pembayaran sebesar 5\% dari nilai. 
Artinya bahwa sebelum penandatanganan kontrak pihak terkait harus menyerahkan bank garansi terlebih dahulu.

Sedangkan berdasarkan SE BI Nomor 23/7/UKU, menyatakan bahwa Bank Garansi merupakan perjanjian buntut dari perjanjian pokok yang telah ada lebih dahulu, maksudnya Bank Garansi akan diterbitkan apabila ada perjanjian yang mendahuluinya. Jadi kedua peraturan tersebut bertentangan sehingga timbulah dilema yang besar antara bank dan penyedia barang/jasa (nasabah). (Wawancara Pada Tanggal 19 Juli 2018).

\subsection{Upaya Bank Untuk Menyelesaikan Permasalahan Mengenai Waktu Penerbitan Bank Garansi}

Sebelum dikeluarkannya Perpres Nomor 95 Tahun 2007 Perubahan Ketujuh Atas Keputusan Presiden Nomor 80 Tahun 2003 tentang Pedoman Pelaksanaan Pengadaan Barang/Jasa Pemerintah, pelaksanaan bank garansi pada BNI Cabang Denpasar berpedoman pada KUH Perdata dan peraturan khusus mengenai bank garansi yakni SEBI Nomor 23/7/UKU Tahun 1971 tentang Pemberian Garansi oleh Bank. Berdasarkan SEBI Nomor 23/7/UKU, suatu bank garansi sekurang-kurangnya memuat ketentuan sebagai berikut:

1. Judul "Garansi Bank" atau "Bank Garansi";

2. Nama dan alamat bank penerbit;

3. Tanggal penerbitan;

4. Transaksi antara pihak yang dijamin nasabah dengan pihak penerima garansi, yaitu perjanjian pokok yang dijamin dengan perjanjian garansi, misalnya tender, pemenuhan bea masuk, pembangunan suatu proyek pemerintah, pengadaan barang pada instansi pemerintah atau swasta, 
pemeliharaan proyek jalan,pembangunan, perijinan perdagangan valuta asing, dan sebagainya.

5. Jumlah uang yang dijamin bank

6. Tanggal mulai berlaku dan berakhir Jangka waktu bank garansi bank bisa sampai dengan maksimal 12 bulan. Pemberian bank garansi dengan jangka waktu melampaui 12 bulan, bisa dipertimbangkan setelah memperoleh izin prinsip dari Direktur Bisnis dan Direktur Pengendalian Kredit yang diajukan melalui Divisi Administrasi Kredit.

7. Penegasan batas waktu pengajuan klaim BG yang diterbitkan harus dengan tegas mencantumkan "bahwa klaim dapat diajukan segera setelah timbul wanprestasi, dengan batas waktu pengajuan terakhir sekurang-kurangnya 14 (empat belas) hari setelah berakhirnya bank garansi tersebut.

Sebagai suatu perjanjian accessoir, maka bank garansi berakhir karena:

1. Berakhirnya perjanjian pokok; atau

2. Berakhirnya bank garansi sebagaimana ditetapkan dalam bank garansi itu sendiri; atau

3. Penegasan batas waktu pengajuan klaim;

Namun setelah dikeluarkan Perpres Nomor 95 Tahun 2007 BNI mengalami kendala mengenai waktu penerbitan bank garansi. Hal ini disebabkan karena adanya norma yang bertentangan pada Peraturan Presiden Nomor 95 Tahun 2007 tentang Perubahan Ketujuh Atas Keputusan Presiden Nomor 80 Tahun 2003 tentang Pedoman Pelaksanaan Pengadaan Barang/Jasa Pemerintah dengan SEBI Nomor 23/7/UKU tahun 1971 tentang Pemberian Garansi oleh Bank. Norma dalam kedua peraturan tersebut bertentangan, 
sehingga menimbulkan permasalahan dalam penerbitan bank garansi.

Untuk menghadapi masalah ini BNI Cabang Denpasar mengambil kebijakan sendiri yakni nasabah yang akan mengajukan permohonan penerbitan bank garansi harus menyerahkan Surat Perintah Kerja (SPK) dari pemberi kerja sebagai underlying transaction dalam penerbitan bank garansi. Namun penerbitan bank garansi yang mengacu kepada SPK tersebut belum dapat mengatasi permasalahan bank garansi, karena mengingat SPK bukanlah perjanjian yang menjelaskan hak dan kewajiban masing-masing pihak, namun baru sepihak saja. Maka dari itu perlu adanya pengkajian terhadap peraturan yang mengatur bank garansi agar dapat mengatasi permasalahan tersebut. (Wawancara Pada Tanggal 19 Juli 2018). 


\section{PENUTUP}

\subsection{KESIMPULAN}

Adapun hasil yang diperoleh dalam penelitian ini adalah sebelum dikeluarkannya Perpres Nomor 95 Tahun 2007, BNI Cabang Denpasar berpedoman pada KUHPer dan peraturan khusus mengenai bank garansi yakni SE BI Nomor 23/7/UKU tentang Pemberian Garansi oleh Bank. Setelah diterbitkannya Perpres 95 Tahun 2007, mengenai prosedur dan syarat penerbitan bank garansi masih sama seperti sebelum terbutnya perpres ini. Namun ada kendala yang dihadapi yaitu mengenai waktu penerbitan bank garansi karena ada ketidaksesuaian peraturan. Untuk menghadapi kendala waktu penerbitan bank garansi bank mengambil kebijakan sendiri yakni dengan mensyaratkan nasabah untuk menyerahkan SPK ( Surat Perintah Kerja) pada saat pengajuan permohonan penerbitan bank garansi. Kasus wanprestasi yang banyak terjadi disebabkan karena kurang ketatnya pengawasan bank terhadap nasabahnya.

\subsection{SARAN}

Mengingat perkembangan masyarakat dan teknologi sudah maju diperlukan adanya penyesuaian terhadap peraturan yang mengatur tentang bank garansi terhadap perkembangan masyarakat pada era sekarang, agar dapat diterapkan dengan baik dalam kehidupan masyarakat. Bank diharapkan dapat meningkatkan sosialisasi ksususnya mengenai bank garansi dan meningkatkan pengawasan terhadap proyek yang dijalankan oleh nasabah (pihak terjamin) agar dapat mengurangi resiko yang dapat merugikan para pihak dalam pelaksanaan bank garansi. 


\section{DAFTAR PUSTAKA}

\section{Buku}

Bambang Sunggono, 2015, Metodologi Penelitian Hukum, Rajawali Pers, Jakarta.

H.Malayu S.P Hasibuan, 2017, Dasar-Dasar Perbankan, Cet ke-11, Bumi Aksara, Jakarta.

H.R. Daeng Naja, 2005, Hukum Kredit dan Bank Garansi, Citra Aditya Bakti, Bandung.

Kasmir, 2016, Dasar-Dasar Perbankan, Rajawali Pers, Jakarta,

P.N.H. Simanjuntak, 2016, Hukum Perdata Indonesia, Cetakan II, Prenadamedia Group, Jakarta.

Salim HS, 2017, Perkembangan Hukum Jaminan di Indonesia, Cet.ke-10, Rajawali Pers, Jakarta.

\section{Jurnal Ilmiah}

Putu Novi Pujayanti, I Nyoman Bagiastra, 2014, Kedudukan Bank Dalam Pemberian Bank Garansi, Vol. 02, No. 05, Juli 2014, Kertha Semaya (URL : https : // ojs.unud.ac.id /index.php /kerthasemaya/article/view/ 9551)

\section{Peraturan Perundang-Undangan}

Kitab Undang-Undang Hukum Perdata (Burgerlijk Wetboek), 2009, Terjemahan Subejti R. Dan R. Tjittrosudibio, Pradnyanan Paramita, Jakarta.

Undang-Undang Nomor 10 Tahun 1998 Tentang Perubahan Atas Undang-Undang Nomor 7 Tahun 1992 tentang Perbankan (Lembaran Negara Republik Indonesia Tahun 1998 Nomor 182, Tambahan Lembaran Negara Republik Indonesia Nomor 3472)

Keputusan Presiden Nomor 80 Tahun 2003 tentang Pedoman Pelaksanaan Pengadaan Barang/Jasa Pemerintah (Lembaran Negara Republik Indonesia Tahun 2003 Nomor 120, Tambahan Lembaran Negara Republik Indonesia Nomor 4330)

Surat Keputusan Direksi Bank Indonesia Nomor 23/88/Kep/Dir tentang Pemberian Bank Garansi.

Surat Edaran Bank Indonesia Nomor 23/7/UKU tentang Pemberian Garansi oleh Bank 
